\title{
Pengaruh Stimulasi terhadap Perkembangan Bicara Anak 1-3 tahun di Daerah GAKY dan Non GAKY
}

\author{
Saldi Fitra, ${ }^{*}$ Asri Purwanti, * Niken Purubita** \\ *Departemen Ilmu Kesehatan Anak Fakultas Kedokteran UNDIP/RSUP Dr. Kariadi, Semarang \\ ** Departemen Gizi Fakultas Kedokteran UNDIP/RSUP Dr. Kariadi, Semarang
}

\begin{abstract}
Latar belakang. Gangguan akibat kekurangan yodium (GAKY) berpengaruh pada tumbuh kembang anak. Gangguan perkembangan bicara pada GAKY terjadi akibat kerusakan otak. Angka kejadian gangguan perkembangan bicara masih cukup tinggi. Stimulasi pada anak di bawah 3 tahun dapat meningkatkan kemampuan bicara berkat kemampuan plastisitas otak.

Tujuan. Menilai pengaruh pemberian stimulasi terhadap perkembangan bicara anak 1-3 tahun di daerah GAKY dan Non GAKY.

Metode. Studi quasi eksperimental one group pretest post test design dengan consecutive sampling dilakukan pada anak 1- 3 tahun yang memenuhi kriteria inklusi di Kecamatan Kepil (non endemis GAKY) dan Kertek (endemis GAKY), Wonosobo, pada bulan April-September 2011. Intervensi stimulasi sesuai dengan pedoman pelaksanaan stimulasi, deteksi dan intervensi dini tumbuh kembang anak di tingkat pelayanan kesehatan dasar 2006. Nilai standar ekuivalen bahasa global dari Early Language Milestones Scale 2 diukur sebelum dan sesudah stimulasi pada daerah GAKY dan Non GAKY. Analisis statistik dengan Paired T-test dan Independent $T$ test.

Hasil. Delapanpuluh anak terdiri dari $57,5 \%$ laki-laki dan $43,5 \%$ perempuan. Rerata nilai perubahan perkembangan bicara daerah GAKY 8,4 (SB 7,94) dan Non GAKY 2,93 (SB 8,3) p= 0,004. Nilai standar ekuivalen perkembangan bicara sebelum dan sesudah diberikan stimulasi di daerah Non GAKY meningkat dari 89,8 menjadi 92,7 (SB 8,3) p=0,032, dan meningkat dari 85,7 menjadi 94 (SB 7,94) (p=0,001) di daerah GAKY.

Kesimpulan. Stimulasi berpengaruh terhadap peningkatan perkembangan bicara anak 1-3 tahun di daerah GAKY dan Non GAKY. Sari Pediatri 2013;15(1):10-6.
\end{abstract}

Kata kunci: stimulasi, perkembangan bicara, gangguan akibat kekurangan yodium

Alamat korespondensi:

Dr. Saldi Fitra, Departemen Ilmu Kesehatan Anak FK UNDIP/RSUP Dr. Kariadi, Jl. Dr. Sutomo 16 Semarang. E-mail: dr_saldifitra@yahoo. com

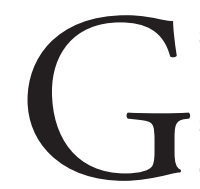

angguan akibat kekurangan yodium (GAKY) merupakan kumpulan gejala akibat kekurangan yodium yang adekuat dalam jangka lama. ${ }^{1}$ Pada anak-anak 
dapat ditimbulkan gangguan tumbuh kembang anak sesuai spektrum GAKY. ${ }^{2}$ Gangguan akibat kekurangan yodium berisiko terhadap 2,2 juta penduduk di seluruh dunia. ${ }^{3}$ Survei nasional evaluasi Intensifikasi Penanggulangan GAKY (IP-GAKY) menunjukkan $35,8 \%$ kabupaten di Indonesia endemis ringan, 13,1\% kabupaten endemis sedang, dan 8,2\% kabupaten endemis berat. ${ }^{4}$ Kabupaten Wonosobo termasuk endemis sedang dengan nilai TGR 24,93\%. Kecamatan Kertek merupakan daerah non endemis GAKY pada tahun 2003 dan endemis ringan pada tahun 2004 dengan TGR 16,8\%. Kecamatan Kepil dengan prevalensi goiter 4,35\% merupakan daerah Non GAKY. ${ }^{5}$

Di masyarakat, GAKY menunjukkan fenoma gunung es dengan kretinisme sebagai puncak. Kerusakan otak minimal seperti gangguan perkembangan bicara lebih banyak terjadi dan tidak terlihat. ${ }^{6}$ Perkembangan bicara dapat dipengaruhi genetik dan lingkungan. ${ }^{7}$ Early language milestones scale 2 (ELMS-2) digunakan untuk menilai perkembangan bicara anak berdasarkan bahasa ekspresif, reseptif, dan visual. ${ }^{8}$

Angka kejadian keterlambatan bicara pada anak masih cukup tinggi. Kejadian gangguan perkembangan bicara anak 0-2 tahun di daerah GAKY (33\%) lebih tinggi dibanding daerah Non GAKY (6,9\%). ${ }^{9}$ Stimulasi pada usia dini menciptakan plastisitas otak sehingga anak dapat tumbuh dan berkembang secara optimal. Periode usia bawah tiga tahun merupakan "golden period" untuk meningkatkan kemampuan potensi anak.

Skrining dini perkembangan bicara pada anak di daerah GAKY dapat membantu untuk mendeteksi gangguan perkembangan bicara sehingga dapat dilakukan intervensi dini sehingga anak dapat tumbuh kembang optimal. ${ }^{10}$ Penelitian ini bertujuan untuk membuktikan pengaruh pemberian stimulasi terhadap perkembangan bicara anak 1-3 tahun di daerah GAKY dan non GAKY.

\section{Metode}

Penelitian quasi eksperimental dengan pre test post test design. Sampel penelitian diambil secara consecutive sampling dari anak usia 1-3 tahun di Kecamatan Kertek (daerah endemis GAKY), dan Kecamatan Kepil (daerah Non endemis GAKY), Kabupaten Wonosobo, Jawa Tengah yang dilakukan intervensi stimulasi dari April sampai September 2011. Berdasarkan rumus besar sampel untuk uji hipotesis untuk 2 proporsi ditetapkan minimal 40 sampel untuk tiap kelompok. ${ }^{11}$ Perkembangan bicara diukur dengan melihat perubahan nilai standar equivalen bahasa global pada ELMS-2 scale. Kriteria inklusi adalah anak usia 1-3 tahun, riwayat bayi lahir normal, sudah tinggal di daerah tersebut dari saat hamil sampai saat penelitian, gizi baik, orang tua tamat SD dan SMP, saat hamil ibu tidak memiliki penyakit kehamilan serta setuju secara tertulis untuk ikut berpartisipasi. Kriteria eksklusi adalah anak dengan gangguan neurologis selama penelitian dan memiliki gangguan pendengaran. Variabel bebas penelitian adalah stimulasi, variabel tergantung adalah perkembangan bicara, dan variabel pengganggu adalah riwayat keluarga dengan gangguan perkembangan bicara, jenis kelamin, sosial ekonomi, dukungan lingkungan keluarga, dan jumlah saudara. Setiap sampel dilakukan wawancara terpimpin dengan kuisioner mengenai identitas dan data dasar, riwayat penyakit anak, riwayat kehamilan dan persalinan, riwayat keluarga, dan lingkungan sosial anak terhadap ibu. Pemeriksaan perkembangan bicara pada subyek dinilai oleh 2 orang dokter (nilai uji $K a p p a=0,656$ ). Stimulasi sesuai panduan pedoman pelaksanaan stimulasi deteksi dan intervensi dini tumbuh kembang anak selama 6 bulan. ${ }^{12}$ Setiap 1 bulan diadakan evaluasi terhadap orang tua dengan bantuan kader Posyandu dan bidan. Perkembangan bicara dinilai kembali setelah 6 bulan. Penelitian ini mendapat persetujuan dari Komite Etik Penelitian Fakultas Kedokteran UNDIP/ RSUP. Dr. Kariadi, Semarang dengan Ethical Clearance No.033/EC/FK/RSDK/2011. Hubungan stimulasi dan perkembangan bicara pada anak 1-3 tahun dianalisis dengan uji korelasi. Hubungan faktor perancu dan perkembangan bicara pada anak 1-3 tahun dianalisis dengan uji Chi-square. Perbedaan antara perkembangan bicara anak 1-3 tahun di daerah GAKY dan non GAKY dianalisis dengan uji t tidak berpasangan. Perbedaan antara perkembangan bicara anak 1-3 tahun sebelum dan sesudah stimulasi di daerah GAKY dan Nnon GAKY dianalisis dengan uji t berpasangan.

\section{Hasil}

Didapatkan subjek penelitian 80 anak. Karakteristik subjek, ibu, keluarga, dan sosial ekonomi tertera pada Tabel 1. Ibu yang bekerja merupakan pegawai swasta, buruh, petani, pedagang, dan pegawai negeri. Rerata nilai sosial ekonomi pada kedua daerah adalah 5 (kategori miskin). 
Tabel 1. Karakteristik subjek

\begin{tabular}{|c|c|c|c|}
\hline \multirow{2}{*}{ Variabel } & \multicolumn{2}{|c|}{ Daerah } & \multirow[b]{2}{*}{$\mathrm{p}$} \\
\hline & Non GAKY & GAKY & \\
\hline Usia (bulan) (rerata, SB) & $22 \pm 5,38$ & $19 \pm 4,72$ & $0,008^{¥}$ \\
\hline \multicolumn{4}{|l|}{ Jenis kelamin (n, \%) } \\
\hline Laki-laki & $21(52,5)$ & $25(62,5)$ & \multirow[t]{2}{*}{$0,366^{\$}$} \\
\hline Perempuan & $19(47,5)$ & $15(37,5)$ & \\
\hline \multicolumn{4}{|l|}{ Tinggi badan (n, \%) } \\
\hline Normal $(-2$ s/d +2SD) & $26(65)$ & $18(45)$ & \multirow[t]{2}{*}{$0,099^{5}$} \\
\hline Pendek dan sangat pendek (<-3 s/d -2SD) & $14(35)$ & $22(55)$ & \\
\hline Riwayat keluarga dengan gangguan perkembangan bicara $(\mathrm{n}, \%)$ & $1(2,5)$ & $2(5)$ & $1,000^{\$}$ \\
\hline Jumlah saudara (rerata, SB) & $0,82 \pm 0,74$ & $0,9 \pm 0,74$ & $0,356^{¥}$ \\
\hline Jumlah penghuni rumah $(\mathrm{n}, \%) \geq 4$ orang & $21(52,5)$ & $33(82,5)$ & $0,004^{\$}$ \\
\hline Bahasa di rumah (f,\%) 2 bahasa & $3(7,5)$ & $2(5)$ & $1,000^{\$}$ \\
\hline \multicolumn{4}{|l|}{ Sosial ekonomi } \\
\hline Miskin (6-14 kriteria) (n,\%) & $12(30)$ & $9(22,5)$ & \multirow[t]{2}{*}{$0,348^{5}$} \\
\hline Tidak miskin (0-6 kriteria) $(\mathrm{n}, \%)$ & $28(70)$ & $22(55)$ & \\
\hline
\end{tabular}

$¥$ Mann Whitney \$Chi-square ¥Mann Whitney

Tabel 2. Perkembangan bicara anak sebelum dan sesudah stimulasi di daerah GAKY dan non GAKY

\begin{tabular}{lccccc}
\hline \multirow{2}{*}{ Variabel } & \multicolumn{2}{c}{ GAKY } & \multicolumn{3}{c}{ Non GAKY } \\
\cline { 2 - 5 } & Nilai & Rerata \pm SB & Nilai & Rerata \pm SB & p \\
\hline Sebelum stimulasi (rentang) & $75-106$ & $85,7 \pm 8,29$ & $69-106$ & $89,8 \pm 8,49$ & $0,030^{\#}$ \\
Sesudah stimulasi (rentang) & $81-110$ & $94 \pm 7,23$ & $69-119$ & $92,72 \pm 8,68$ & $0,478^{\#}$ \\
Stimulasi & & $4 \pm 1,05$ & & $4 \pm 0,97$ & $0,66^{\#}$ \\
Adanya dukungan keluarga & $7(17,5)$ & & $23(57,5)$ & & $0,0001^{\$}$ \\
Perubahan bahasa reseptif (rerata, SB) & & $9,8 \pm 1,23$ & & $1,1 \pm 8,99$ & $0,001^{\#}$ \\
Perubahan bahasa ekspresif (rerata, SB) & & $1,9 \pm 1,26$ & & $-0,5 \pm 1,08$ & $0,367^{\#}$ \\
\hline
\end{tabular}

\# Independent sample T-test \$Chi-square

Perkembangan bicara anak dipengaruhi oleh banyak faktor, di antaranya stimulasi, status gizi, kadar yodium, dukungan lingkungan keluarga, endokrin, jumlah saudara, jenis kelamin, pendidikan ibu, sosial ekonomi, riwayat keluarga dengan gangguan bicara, imunisasi, infeksi intra kranial, pelayanan kesehatan, dan lain-lain. Tabel 2 menunjukkan perkembangan bicara anak sebelum dan sesudah stimulasi menurut nilai standar ekuivalen bahasa global ELMS-2, stimulasi, adanya dukungan keluarga, perubahan bahasa reseptif dan ekspresif di daerah GAKY dan Non GAKY.

Rerata nilai $H O M E$ inventory di daerah non GAKY adalah 61,9 (SB 17,2), dan 54,3 (SB 6,3) di daerah GAKY ( $\mathrm{p}=0,0001)$. Rerata nilai sebelum dan sesudah stimulasi untuk perkembangan bicara berbeda di daerah non GAKY $(\mathrm{p}=0,032)$, dan daerah GAKY ( $\mathrm{p}=0,001)$ (paired T test).

Analisis bivariat menunjukkan adanya hubungan antara stimulasi $(\mathrm{p}=0,026)$ dan jumlah saudara ( $\mathrm{p}=0,043$ ) dengan perkembangan bicara di daerah GAKY. Tidak didapatkan hubungan antara variabel lainnya dengan perkembangan bicara di daerah GAKY dan non GAKY.

Berdasarkan analisis regresi didapatkan hubungan antara stimulasi dan jumlah saudara dengan perkembangan bicara di daerah GAKY dengan persamaan $\mathrm{Y}=0,746+(0,140) \mathrm{X}_{1}+(0,339) \mathrm{X}_{2},(\mathrm{Y}=$ perkembangan bicara, $\mathrm{X}_{1}$ stimulasi, dan $\mathrm{X} 2$ jumlah saudara) $\mathrm{p}=0,011$. Pembahasan 
Usia $<24$ bulan cenderung lebih banyak mengalami perubahan perkembangan bicara setelah stimulasi. Pertumbuhan otak pada usia 24 bulan sudah mencapai $80 \%$ ukuran otak dewasa. Gangguan perkembangan bicara yang diketahui sejak dini dapat diperbaiki dengan pemberian intervensi yang sesuai. ${ }^{13}$

Gangguan pertumbuhan akibat GAKY ditunjukkan oleh perawakan pendek pada anak. ${ }^{1,14,15}$ Perawakan pendek pada daerah endemis GAKY merupakan akibat dari kekurangan yodium yang berpengaruh pada pertumbuhan anak. ${ }^{3,6,14}$ Tidak didapatkan hubungan antara jenis kelamin dan perkembangan bicara pada daerah GAKY dan non GAKY. Engle dan Levine ${ }^{16}$ menyatakan bahwa secara biologis dan genetis tidak terdapat perbedaan bawaan potensi perkembangan antara anak laki-laki dengan anak perempuan.

Ibu memiliki kedekatan hubungan dengan anak yang dapat mempengaruhi perkembangan bicara. ${ }^{13}$ Semakin tinggi pendidikan seseorang maka semakin baik tingkat pengetahuannya. Pendidikan orang tua berhubungan dengan dukungan lingkungan keluarga yang diberikan. Novera ${ }^{17}$ mengatakan bahwa semakin tinggi tingkat pendidikan ayah dan ibu, semakin besar stimulasi psikososial yang diberikan kepada anak. Pendidikan ibu rendah berhubungan dengan terlambatnya perkembangan bicara. ${ }^{18,19,20,21} \mathrm{Hal}$ tersebut berhubungan dengan pengetahuan, motivasi, dan kemudahan menerima informasi.

Sebagian besar ibu tidak bekerja sehingga berkesempatan lebih banyak untuk memberikan stimulasi. Berdasarkan pengamatan dan pertanyaan kepada ibu, peneliti berasumsi bahwa ibu yang tidak bekerja lebih banyak mengerjakan pekerjaan harian rumah tangga dan sedikit waktu tersisa digunakan untuk bermain bersama anak.

Lingkungan mini yang terdiri dari anggota keluarga lain menjadi penunjang terhadap peran ibu dalam mengoptimalkan tumbuh kembang anak. ${ }^{13}$ Riwayat keluarga dengan gangguan bicara tidak berhubungan dengan perkembangan bicara di daerah GAKY dan Non GAKY. Riwayat keluarga dengan gangguan perkembangan bicara berhubungan dengan perkembangan bicara. ${ }^{22,23,24}$ Penelitian tersebut menjelaskan adanya pengaruh gen spesifik pada fenotipe bicara dan bahasa. Pola bicara yang abnormal dari keluarga ditransmisikan secara budaya atau dengan memberikan pengaruh kepada lingkungan oleh anggota keluarga yang terlambat bicara. ${ }^{22}$
Jumlah saudara pada daerah GAKY berhubungan dengan perkembangan bicara. Jumlah saudara berhubungan dengan jumlah anak dalam keluarga. Jumlah anak yang banyak akan mengakibatkan berkurangnya perhatian, kasih sayang, dan kebutuhan primer anak. ${ }^{13}$ Eko $^{7}$ melaporkan tidak didapatkan hubungan antara jumlah saudara dengan perkembangan bicara.

Sosial ekonomi tidak berhubungan dengan perkembangan bicara di daerah GAKY dan Non GAKY. Barros dkk, ${ }^{25}$ Evan, ${ }^{19}$ dan Hart ${ }^{26}$ melaporkan adanya hubungan antara sosial ekonomi dan perkembangan bicara. Ekonomi merupakan prediktor lingkungan untuk memperkirakan keberhasilan perkembangan anak. Hubungan dan pengaruh sosial ekonomi terhadap perkembangan bicara bergantung pada indikator yang dipakai. Terpenting adalah bagaimana kondisi sosial ekonomi mempengaruhi interaksi hubungan anak dengan lingkungan dalam mempengaruhi tumbuh kembang anak. ${ }^{7}$

Dukungan lingkungan keluarga (nilai $H O M E$ inventory), tidak berhubungan dengan perkembangan bicara. Martha $\mathrm{dkk}^{27}$ menunjukkan bahwa stimulasi lingkungan berhubungan dengan perkembangan bicara. Anak yang lebih banyak mendapatkan informasi dari buku, permainan atau rekreasi yang diberikan oleh lingkungan keluarga baik ibu atau pengasuh lainnya akan merangsang perkembangan bicara. Penilaian yang digunakan adalah ada atau tidaknya keterlambatan bicara. Parameter penilaian HOME Inventory sebaiknya disesuaikan dengan keadaan di Indonesia sehingga dapat dijadikan alat pengukuran yang baik.

Periode perkembangan otak yang rawan untuk terjadinya gangguan hormon tiroid pada trimester tiga sampai 2 atau 3 tahun pertama kehidupan, berhubungan dengan multipikasi sel glia, migrasi dan myelinisasi. ${ }^{28}$ Studi pada janin hewan coba membuktikan bahwa kekurangan yodium akan menghasilkan berat otak yang lebih rendah, pengurangan jumlah sel otak, dan keterlambatan perkembangan serebelum. ${ }^{29}$ Stimulasi selama periode 3 tahun pertama kehidupan dapat menentukan sinaptogenesis, mielinisasi, dan hubungan sinaptik. ${ }^{30}$ Barros $\mathrm{dkk}^{25}$ mengatakan bahwa perkembangan anak berhubungan kuat dengan sosial ekonomi, pendidikan ibu dan stimulasi. Peningkatan perubahan perkembangan bicara pada daerah GAKY lebih besar di banding daerah GAKY dan berbeda bermakna secara statistik. Stimulasi memiliki hubungan bermakna dengan perkembangan bicara di 
daerah GAKY.

Perkembangan anak pada usia 0-3 tahun sangat peka terhadap stimulus dan pengalaman serta mempunyai kemampuan plastisitas yang tinggi. ${ }^{30}$ Struktur kimia DNA dan struktur fisik otak dapat diubah oleh pengalaman sosial dengan cara memengaruhi ekspresi gen sehingga dapat bertahan seumur hidup. Stimulasi yang optimal akan mengoptimalisasi pertumbuhan otak. Sinaptogenesis yang didukung oleh stimuli eksternal akan meningkat pesat. ${ }^{30,31}$ Kami mendapatkan perbedaan yang bermakna secara statistik antara rerata nilai sebelum dan sesudah diberikan stimulasi. Tidak didapatkan perbedaan rerata nilai perkembangan bicara sesudah stimulasi antara daerah GAKY dan Non GAKY. Didapatkan peningkatan perkembangan berbicara pada daerah GAKY dan Non GAKY setelah diberikan stimulasi. Berdasarkan pengamatan dan wawancara dengan orang tua dan kader Posyandu didapatkan perbedaan keterlibatan perangkat desa dan petugas kesehatan di daerah GAKY dan Non GAKY. Di daerah non GAKY, hanya bidan dan kader Posyandu yang berperan aktif dalam proses stimulasi. Di daerah GAKY didapatkan peran kader posyandu, bidan desa, dan Ketua PKK dalam proses stimulasi. Hal tersebut mungkin menjadi penyebab pemberian stimulasi yang diberikan oleh orang tua pada daerah GAKY lebih baik walaupun tidak didapatkan perbedaan frekuensi stimulasi antara daerah GAKY dan Non GAKY. Pengaruh lingkungan makro seperti pemerintah desa dan PKK di daerah GAKY dalam perkembangan anak khususnya perkembangan bicara dapat dilihat pada penelitian kami. ${ }^{13}$ Keberadaan saudara berpengaruh terhadap perkembangan bicara anak. Anak lebih banyak bermain, berinteraksi, dan mendapatkan contoh dalam bentuk gerak badan, percakapan maupun makna suatu hal dari saudara yang lebih tua atau teman bermain. ${ }^{32}$ Jumlah saudara di daerah GAKY berhubungan dengan perkembangan bicara berdasarkan analisis regresi mempunyai pengaruh lebih banyak terhadap perubahan perkembangan bicara dibandingkan stimulasi. Faktorfaktor lain yang dapat memengaruhi perkembangan bicara tidak dibahas pada penelitian kami yang mungkin dapat berpengaruh pada perkembangan bicara anak. Analisis multivariat diperlukan untuk menyingkirkan faktor pengganggu.

Gangguan bahasa reseptif merupakan salah satu akibat dari kerusakan minimal otak pada daerah GAKY. ${ }^{1}$ Stimulasi yang diberikan berpengaruh terhadap bahasa reseptif dan bahasa ekspresif. Pada peneliti- an kami, tidak didapatkan perbedaan perubahan bahasa ekspresif antara daerah GAKY dan Non GAKY. Kerusakan otak menimbulkan gangguan pada pusat bicara sehingga anak sulit mengolah informasi yang diberikan dan tidak bisa mengungkapkan kata atau ide. Belum optimalnya stimulasi yang diberikan orang tua, dan lingkungan membuat bahasa ekspresif anak tidak mengalami perubahan.

Sulit untuk melakukan perhitungan perubahan bahasa visual. Semua item bahasa visual dapat dilakukan oleh semua subyek penelitian pada pemeriksaan awal dan akhir, dan penilaian maksimal hanya bisa dilakukan sampai usia 18 bulan. Pemeriksaan akhir setelah 6 bulan, hanya ada 1 subyek yang berusia 18 bulan, dan sisanya berusia $>18$ bulan.

Keterbatasan penelitian kami, yaitu 1) data prevalensi daerah GAKY yang dipergunakan adalah data tahun 2004 dan belum ada data baru, 2) pemeriksaan kadar konsumsi yodium saat ibu hamil tidak dilakukan karena diasumsikan sudah terjadi dan tidak ada data, 3) tidak dilakukan pemeriksaan pendengaran dengan uji OAE dan BERA karena keterbatasan biaya dan peralatan, 4) plastisitas otak tidak dapat diukur karena keterbatasan instrumen pengukuran, 5) pemeriksaan kadar UIE dan Goiter rate tidak dilakukan karena hasil pemeriksaan tidak dianalisis, 6) perkembangan bicara dipengaruhi oleh banyak faktor, namun pada penelitian ini hanya melihat beberapa faktor, 7) analisis multivariat tidak dilakukan untuk memperhitungkan faktor perancu.

\section{Kesimpulan}

Perkembangan bicara pada anak 1-3 tahun sebelum stimulasi di daerah non GAKY lebih baik dibandingkan daerah GAKY. Tidak didapatkan perbedaan perkembangan bicara pada anak 1-3 tahun sesudah stimulasi di daerah GAKY dan Non GAKY. Stimulasi berpengaruh terhadap peningkatan perkembangan bicara anak 1-3 tahun di daerah GAKY dan Non GAKY. Program stimulasi, deteksi dini, dan intervensi dini tumbuh kembang anak agar dilakukan lebih intensif dan dilakukan sampai tingkat kader dan orang tua di bawah pengawasan pihak terkait untuk mengoptimalkan perkembangan anak. Perlu dilakukan penelitian lebih lanjut mengenai faktor risiko yang berpengaruh terhadap perkembangan bicara khususnya di daerah GAKY. 


\section{Daftar pustaka}

1. World Health Organization. Assessment of iodine deficiency disorders and monitoring their elimination: A guide for programme managers. Third edition. Geneva, Switzerland: World Health Organization Press. [Online] 2007 pada tanggal 31 Mei 2008; Didapat dari: http:// whqlibdoc.who.int/publications/2007/9789241595827_ eng.pdf.

2. ICCIDD. About iodine deficiency disorder. New Orleans: Tulane University School of Public Health and Tropical Medicine. Pada tanggal 31 Mei 2008; Didapat dari: http://www.tulane.edu/-iceclaboutidd.htm.

3. Lee SL. Iodine deficiency. [Online]. 2006. pada tanggal 31 Mei 2008. Didapat dari: http://emedicine.medscape.com/ article/122714-overview.

4. Rencana Aksi Nasional Kesinambungan Program Penanggulangan GAKY. pada tanggal 23 Agustus 2008. Didapat dari: http://www.gizi.net/gaky/exit\%20gaky.pdf.

5. Dinas Kesehatan provinsi Jawa Tengah. Profil kesehatan provinsi jawa tengah tahun 2007. Semarang: Dinas Kesehatan Provinsi Jawa Tengah; 2007.

6. Hartono B. The influence of iodine deficiency during pregnancy on neurodevelopment from birth to two years. Semarang: Diponegoro University Press; 2001.

7. Jaenudin E. Pengaruh stimulasi keluarga terhadap perkembangan bicara anak. Tesis. Semarang: Universitas Diponegoro; 2000.

8. Myklebust M. Prelinguistic Communication. Dalam: Yule W, Rutter M, penyunting. Language development and disorders; Clinics in developmental medicine. 1968.

9. Hartono B, Njiokiktjien C, Veerman AJP, de Sonneville $\mathrm{L}$. The influence of iodine deficiency during pregnancy on child neurodevelopment 0-24 months of age in East Java, Indonesia. Neurology Asia 2005;10:113-24.

10. Trimarchi F, Vermiglio F, Finocchiaro MD, Battiato S, Lo Presti VP, La Torre N dkk. Epidemiology and clinical characteristics of endemic cretinism in Sicily.J Endocrinol Invest. 1990;13:543-8.

11. Madiyono B, Moeslichan S, Sastroasmoro S, Budiman I, Purwanto H. Perkiraan besar sampel. Dalam: Sastroasmoro S, Ismael S, penyunting. Dasar-dasar metodologi penelitian klinis. Edisi ke-3. Jakarta:Sagung Seto;2008.h. 311-4.

12. Direktorat Bina Kesehatan Anak Departemen Kesehatan Republik Indonesia. Pedoman pelaksanaan stimulasi, deteksi dan intervensi dini tumbuh kebang anak di tingkat pelayanan kesehatan dasar. Jakarta: Departemen
Kesehatan Republik Indonesia; 2006.

13. Soetjiningsih, Tumbuh kembang anak. Dalam: Ranuh IG.N Gde, penyunting. Jakarta: EGC. 2005.h.1-32.

14. Djokomoeljanto. Spektrum klinik gangguan akibat kekurangan yodium: dari gondok hingga kretin endemik. Jurnal GAKY Indonesia 2002;3:1-5.

15. Mastorakos G, Nezi M, Papadopoulos C. The iodine deficiency disorders. Dalam: Thyroid disease manager. chapter 20. pada tanggal 27 Mei 2008. Didapat dari: http://www.thyroidmanager.org/Chapter20/20-frame. htm.

16. Engle PL, Levin RJ. Sex differences in the effect of malnutrition on mental development : A review and some hypotheses. Dalam: Brozek, Schurch, Malnutrition and behavior: Critical assessment of key issues; An International Symposium at a Distance 1983-1983, Nestle Foundation, Laussane 1984: 396-410.

17. Rahmaulina NR, Hastuti D. Hubungan pengetahua ibu tentang gizi dan tumbuh kembang anak serta stimulasi psikososial dengan perkembangan kognitif anak usia 2-5 tahun. Skripsi. Bogor: Institut Pertanian Bogor; 2007.

18. Walker SP, Wachs TD, Meeks Gardner J,. Child development: risk factors for adverse outcomes in developing countries. Lancet 2007;369:145-57.

19. EvansGW, English K. The environment of poverty: Multiple stressor exposure, psychophysiological stress, and socioe-motional adjustment. Child Development 2002;73: 1238-48.

20. Halpern R. Early childhood intervention for low-income children and families. Dalam: JP Shonkoff, SJ Meisels, editors. Handbook of early childhood intervention. Edisi ke-2. Cambridge, England: Cambridge University Press; 2000.h.361-86.

21. Ginsborg J. The effects of socio-economic status on children's language acquisition and use. Clegg J, Ginsborg J, penyunting. [Online]. 2006. Available from: language and social disadvantage: Theory into practice. John Wiley \& Sons, Ltd. [cited 2008 Aug 27].

22. Campbell TF, Dollaghan CA, Rockette HE, Paradise JL, Feldman HM, Shroberg LD, dkk. Risk factors of speech delay of unknown origin in 3-year old children. Child development. Mar-Apr 2003;74:346-57. Didapat dari: http://polygoinsurance.com/ref_health_insuranceresearch. html.

23. Rodrigue TM. Prevalence of family history of speechlanguage impairment in an African American sample. Thesis. Louisiana State University; 2003

24. Reilly S, Wake M, Bavin EL, Prior M, Williams J, Bretherton L, dkk. Predicting Language at 2 Years 
of Age: A Prospective Community Study. Pediatrics 2007;120;1441-9

25. Barros AJD, Matijasevich A, Santos IS, Halpern R. Child development in a birth cohort: effect of child stimulation is stronger in less educated mothers. Inter J Epidemiol 2010;39:285-94.

26. Hart D, Atkins R,Matsuba MK. The association of neighborhood poverty with personality change in childhood. J Personality and Soc Psychol 2008;94:104861.

27. Farah MJ, Betancourt L, Shera DM, Savage JH, Giannetta JM, Brodsky NL, dkk. Environmental stimulation, parental nurturance and cognitive development in humans.Developmental Science 2008;11:793-801.

28. de Escobar M, Obregon MJ, del Rey E. Is neuropsychological development related to maternal hypo- thyroidism or to maternal hypothyroxinemia? J Clin Endocrinol. Metab 2000;85:3975-87.

29. DelangeF, Hetzel BS. The scientific basis for the elimination of brain daphage due to iodine deficiency. Section IV. In global fimination of brain damage due to iodine deficiency. Didapat ..... pada tanggal $10 \mathrm{Juli}$ 2008

30. Mundkur. Neuroplasticity in children. Indian J Pediatr 2005;72:855-7.

31. Robert C. Synaptic Plasticity. Neuropsychopharmacology 2002;11:148-57.

32. Ervin-tripp S. Play in language development. In: Scales B, Almy M, Nicolopoulou A, Ervin-Tripp S, penyunting. Play and the social context of development in early care and education. Chapter 6. New York: Teachers College Press; 1991.h.85-97. 